\title{
UJI AKTIVITAS ANTIBAKTERI FRAKSI N-HEKSANA, METANOL DAN AIR DARI ASCIDIAN Lissoclinum sp.
}

\author{
(Antibacterial Activity Assay of n-Hexane, Methanol, Water Fraction from Ascidian \\ Lissoclinum $s p$.)
}

\author{
Samuel L. Opa ${ }^{1 *}$, Robert A. Bara ${ }^{1}$, Grevo S. Gerung ${ }^{1}$, Rizald M. Rompas ${ }^{1}$, \\ Rosita A.J. Lintang ${ }^{1}$, Deiske A. Sumilat ${ }^{1}$
}

1. Program Studi IImu Kelautan, Fakultas Perikanan dan IImu Kelautan, Universitas Sam Ratulangi, Manado.

*e-mail : samueloppa@gmail.com

Ascidians are marine invertebrates known to produce bioactive compounds such as antibacterials. The aims of this research is to determine the effectiveness of $n$-hexane, methanol, and water fractions from ethancolic extract ascidian Lissoclinum sp. as an antibacterial to 2 species of Gram-positive bacteria Staphylococus saprophyticus and Bacillus megaterium and 2 species of Gram-negative bacteria namely Pseudomonas aeruginosa and Escherechia coli. The extraction begins with 3 times sample maceration using 95\% ethanol for and then the filtrate obtained is evaporated with a Rotary vacuum evaporator. The extract obtained was fractionated by partition method using $n$-hexane, methanol, and water. The antibacterial activity assay method used was agar diffusion (disc diffusion Kirby and Bauer) which have been modified. The results obtained were obtained antibacterial activity of the water fraction and antibacterial activity was shown to the four assay bacteria and explained the antibacterial compound is broad spectrum.

Keywords: ascidian, Lissoclinum sp., antibacterial, partition.

Ascidian adalah avertebrata laut yang diketahui memproduksi senyawa bioaktif seperti antibakteri. Tujuan dari penelitian ini adalah untuk mengetahui efektiviitas fraksi n-heksana, metanol, dan air dari ekstrak etanolik ascidian Lissoclinum sp. sebagai antibakteri terhadap 2 spesies bakteri Gram positif Staphylococus saprophyticus dan Bacillus megaterium serta 2 spesies bakteri Gram negatif yaitu Pseudomonas aeruginosa dan Escherechia coli. Ekstraksi diawali dengan Maserasi sampel menggunakan etanol 95\% selama tiga kali dan kemudian filtrat yang didapatkan dievaporasi dengan Rotary vacuum evaporator. Ekstrak yang didapatkan difraksinasi dengan metode Partisi menggunakan pelarut n-Heksana, metanol, dan air. Metode Pengujian aktivitas antibakteri yang digunakan adalah difusi agar (disc diffusion Kirby and Bauer) yang telah dimodifikasi. Hasil yang diperoleh yaitu didapatkan aktivitas antibakteri dari fraksi air dan aktivitas antibakterinya ditunjukkan terhadap keempat bakteri uji dan menjelaskan senyawa antibakteri tersebut berspektrum luas.

Kata kunci: ascidian, Lissoclinum sp., antibakteri, partisi.

\section{PENDAHULUAN}

Keanekaragaman organisme laut Indonesia yang sangat tinggi memiliki potensi untuk menyokong perekonomian negara, contohnya Perairan Bunaken yang menjadi sumber penghasilan andalan pemerintah Sulawesi Utara (Wagey, 2017). Keanekaragaman organisme (biodiversity) laut juga mempunyai arti keanekaragaman senyawa kimia (chemodiversity) yang terkandung dalam organisme. Senyawa-senyawa tersebut dapat memiliki aktivitas biologis yang bervariasi. Bahan alam laut berupa senyawa-senyawa kimia tersebut berpotensi dikembangkan sebagai bahan obat (Dahuri, 2003). Diketahui bahwa beberapa biota laut dapat menghasilkan bahan hayati yang memiliki aktivitas biologis di antaranya yaitu bryozoa (Sima dan Vetvicka, 2011), moluska (Kiran et al., 2014), spons (Ngantung et al., 2016, Luissandy et al., 2017, Pasodung et al., 2018, Nowin et al., 2018), karang lunak (Kawung et al., 2017) dan ascidian (Ali andTamilselvi, 2016). 
Ascidian adalah avertebrata laut yang digolongkan dalam filum Chordata, sub-filum Tunikata atau juga dikenal sebagai Urochordata dari kelas Ascidiacea. Ascidian terdapat hampir di seluruh laut di dunia. Namun, ascidian umumnya terdapat di perairan litoral pada zona intertidal hingga subtidal, menempel pada karang, cangkang moluska, lambung kapal, atau pada dasar pasir dan lumpur (Shenkar and Loya, 2008; Ompi, 2016).

Senyawa bioaktif yang disintesis oleh ascidian merupakan metabolit sekunder, yaitu metabolit turunan secara biosintetik dari metabolit primer yang digunakan dalam sistem pertahanan diri, yaitu untuk mempertahankan hidup dan menghindari gangguan dari organisme lain di lingkungan tempat hidupnya. Karena aktivitas farmakologinya maka senyawa tersebut memiliki prospek untuk diisolasi dan dimanfaatkan dalam bidang farmasi (Sumilat, 2018). Diketahui dari ascidian sudah ditemukan berbagai senyawa dengan bioaktivitas seperti larvasida (Rumengan, 2010; Mangindaan dan Taroreh, 2013; Moerid et al., 2013), antikanker/antitumor (Nakamura et al., 2013; Sumilat et al., 2014; Wewengkang et al., 2014; Sumilat et al., 2017; Tatsuta et al., 2017; Urda et al., 2017), antidiabetes (Li, 2012), antiinflamasi (Chan et al., 2011), antivirus (Donie et al., 2008), dan antibakteri (Wang et al., 2008). Pencarian senyawa antibakteri dari ascidian perlu dilakukan untuk mendapatkan obat antibakteri baru, mengingat telah begitu banyak infeksi dan penyakit yang disebabkan oleh bakteri.

Pencarian senyawa bioaktif dari ascidian di beberapa perairan di Indonesia sudah dilakukan, namun masih banyak lokasi di Indonesia yang belum tersentuh. Perairan Pangalisang Bunaken merupakan wilayah perairan yang memiliki areal terumbu karang yang baik sehingga tidak diragukan lagi wilayah ini memiliki keanekaragaman organisme laut. Namun sayang sekali bahwa usaha yang dilakukan untuk mengeksplorasi dan mengeksploitasi bahan-bahan aktif dari biota laut tersebut masih sangat sedikit. Dengan demikian perlu dilakukan penelitian mengenai biota laut khususnya ascidian dalam upaya pemanfaatan senyawa bioaktif yang nantinya dapat dijadikan bahan baku pembuat bahan farmasi.

\section{METODE PENELITIAN}

\section{Waktu dan Tempat Penelitian}

Rangkaian Penelitian dimulai pada Maret 2018 dan berakhir pada April 2018. Tempat Penelitian yaitu Perairan Pangalisang Pulau Bunaken (Gambar 1) sebagai lokasi pengambilan sampel selanjutnya yaitu Laboratorium Biologi Molekuler dan Farmasetika Laut Fakultas Perikanan dan IImu Kelautan Universitas Sam Ratulangi Manado di mana dilakukan proses ekstraksi, partisi dan pengujian aktivitas antibakteri

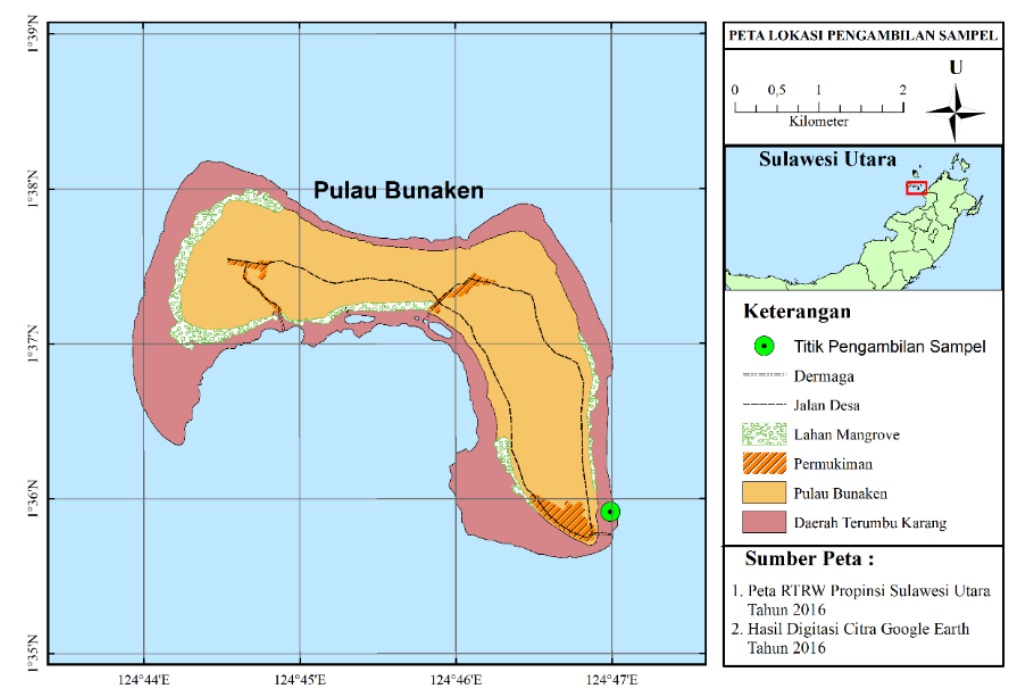

Gambar 1. Peta Pengambilan Sampel 


\section{Pengambilan dan Identifikasi Sampel}

pada kedalaman air 5-7 meter menggunakan alat bantu satu set alat snorkeling dan sebuah pisau. Setelah diambil dilakukan identifikasi sampel. Pengidentifikasian sampel ascidian dilakukan dengan melihat bentuk, warna, dan struktur spons. Identifikasi dilakukan dengan dipandu buku pedoman Colin dan Arneson (1995).

\section{Alat dan Bahan}

Peralatan yang digunakan pada penelitian ini, antara lain autoklaf, 1 set rotary vacuum evaporator, laminar air flow, corong pisah, statif, corong kaca, kertas saring, mikropipet, kertas cakram, timbangan analitik, erlenmeyer, cawan petri, alumunium foil, mistar.

Bahan yang digunakan adalah agar, pepton, natrium klorida $(\mathrm{NaCl})$, ekstrak daging (meat extract), kloramfenikol, etanol 95\%, metanol, nHeksana, etil asetat, air dan sampel ascidian Lissoclinum sp.

\section{Sterilisasi Alat Dan Bahan}

Peralatan kaca sepert cawan petri dan erlenmeyer dicuci bersih dikeringkan lalu dibungkus dengan kertas alumunium foil dan dimasukkan ke dalam oven pada suhu $160^{\circ}$ selama kurang lebih dari 2 jam atau diatutoklaf pada suhu $121^{\circ} \mathrm{C}$ selama 15 menit. Kemudian untuk media cair dan padat B1, semua bahan dimasukkan dalam gelas erlenmeyer lalu ditutup dengan alumunium foil kemudian disterilkan dengan autoklaf pada suhu $121^{\circ} \mathrm{C}$ selama 15 menit.

\section{Ekstraksi Ascidian}

Sampel ascidian Lissoclinum sp. dimaserasi bertahap selama 3 kali dalam larutan etanol selama 24 jam selanjutnya untuk mendapatkan filtrat disaring menggunakan kertas cakram whattman dan kemudian filtrat dievaporasi menggunakan rotary vacuum evaporator pada suhu $40^{\circ}$ hingga etanol terevaporasi sempurna dan tersisa ekstrak kasar. Kemudian ekstrak kasar diambil menggunakan spatula dan dimasukkan ke dalam botol ekstrak.

\section{Penyiapan Peralatan dan Larutan Partisi}

Disiapkan 4 gelas erlenmeyer dan dimasukkan masing-masing aquades 200 $\mathrm{ml}$, etanol $200 \mathrm{ml}$, etil asetat $200 \mathrm{ml}$, nheksana $200 \mathrm{ml}$ kemudian seluruh elenmeyer ditutup dengan aluminium foil. Setelah seluruh larutan sudah siap dipakai, peralatan seperti corog pisah dan statif diambil dan kemudian corong pisah diletakkan pada bagian penahan dari statif. Selanjutnya 4 buah erlenmeyer disiapkan untuk menampung fraksi.

\section{Partisi}

Setelah semua pelarut dan peralatan selesai disiapkan, ekstrak etanol Lissoclinum sp. yang telah dievaporasi dan diperoleh ekstrak etanolnya diambil sebanyak $15 \mathrm{~g}$ dan dimasukkan ke dalam corong pisah yang berisi aquades sebanyak $200 \mathrm{ml}$ dan etil asetat sebanyak $200 \mathrm{ml}$ Kemudian corong pisah diambil dari statif dan dikocok-kocok hingga tercampur ekstrak etanol dan kedua pelarut partisi. Setelah itu dikembalikan lagi ditempatkan pada statif sekitar 5 menit. Lapisan air diambil dengan membuka keran pada corong pisah serta penutup corong pisah. Fraksi air ditampung pada erlenmeyer 250 $\mathrm{ml}$ hingga semua lapisan air terambil lalu keran segera ditutup agar tidak ada fraksi etil asetat yang ikut terambil. Selanjutnya fraksi etil asetat juga ditampung pada erlenmeyer $250 \mathrm{ml}$. Kedua fraksi yang didapatkan yakni fraksi air dan fraksi etil asetat dievaporasi dengan menggunakan rotary vacuum evaporator. Proses evaporasi untuk fraksi air membutuhkan waktu yang cukup lama dibandingkan waktu untuk mengevaporasi fraksi etil asetat dikarenakan evaporasi dilakukan pada suhu $40^{\circ} \mathrm{C}$ untuk menjaga keadaan senyawa yang terkandung pada setiap fraksi agar tidak rusak dan air merupakan pelarut yang susah menguap pada tingkatan suhu seperti ini.

Selanjutnya fraksi etil asetat dipartisi kembali menggunakan metanol sebanyak $200 \mathrm{ml}$ dan n-heksana sebanyak 200 ml. Labu evaporasi yang berisikan hasil evaporasi fraksi etil asetat ditambahkan metanol secukupnya setelah itu dituang ke dalam corong pisah. Selanjutnya dituang keseluruhan metanol 
dan n-heksana untuk partisi. Kemudian corong pisah diangkat dari statif dan dikocok-kocok sekitar 1 menit dan kembali ditempatkan pada statif seperti sebelumya sampai terlihat kedua pelarut terpisah. Lapisan metanol diambil dengan membuka keran pada corong pisah serta penutup corong pisah. Fraksi metanol ditampung pada erlenemyer $250 \mathrm{ml}$ hingga semua lapisan air terambil lalu keran segera ditutup agar tidak ada fraksi n-heksana yang ikut terambil. Selanjutnya fraksi nheksana diambil dengan membuka keran pada corong pisah dan penutup corong pisah. Fraksi n-heksana ditampung pada erlenmeyer $250 \mathrm{ml}$ juga. Kedua fraksi ini dievaporasi dan kemudian akan diambil menggunakan spatula dan dipindahkan ke botol sampel kecil bersamaan dengan fraksi air yang sudah dievaporasi terlebih dahulu. Selanjutnya ketiga fraksi ditimbang menggunakan timbangan analitik.

\section{Pembuatan Media Cair B1}

Media Cair B1 untuk kultur bakteri dilakukan menggunakan 4 erlenmeyer untuk keempat bakteri uji. Bahan-bahan yang digunakan ditimbang hingga tertakar $0,25 \mathrm{~g}$ pepton, $0,15 \mathrm{~g} \mathrm{NaCl}$ dan $0,15 \mathrm{~g}$ ekstrak daging dan dimasukkan ke tiap erlenmeyer lalu dimasukkan aquades sebanyak $50 \mathrm{ml}$. Keempat erlenmeyer yang telah berisikan bahan diaduk hingga homogen lalu ditutup dengan alumunium foil, kemudian keempat erlenmeyer dimasukkan ke dalam autoklaf untuk disterilkan pada suhu $121^{\circ} \mathrm{C}$ selama 15 menit.

\section{Kultur Bakteri}

Setelah media cair B1 sudah selesai disterilasasi, keempat erlenmeyer diberi label dam dibawa ke laminar air flow. Kemudian masing-masing bakteri diambil dari dalam tabung reaksi dan dimasukkan ke dalam masing-masing erlenmeyer menggunakan jarum ose. Jarum ose harus dibakar pada lampu bunsen sebelum mengambil bakteri yang lain dan setelah pemakaian. Setelah itu masing-masing erlenmeyer ditutup dengan alumunium foil dan diinkubasi selama 1x24 jam pada suhu ruang.

\section{Pembuatan Kontrol}

Kontrol positif dibuat dari $500 \mathrm{mg}$ kloramfenikol yang dilarutkan dalam $3 \mathrm{ml}$ aquades (200.000 ppm). Sedangkan kontrol negatif menggunakan pelarut metanol.

\section{Pembuatan Media Padat B1}

Media padat B1 untuk kultur bakteri dilakukan menggunakan 4 erlenmeyer untuk keempat bakteri uji. Bahan-bahan yang digunakan ditimbang hingga tertakar $1,5 \mathrm{~g}$ agar, $0,50 \mathrm{~g}$ pepton, $0,15 \mathrm{~g} \mathrm{NaCl}$ dan $0,15 \mathrm{~g}$ ekstrak daging dan dimasukkan ke tiap erlenmeyer lalu dimasukkan aquades sebanyak $100 \mathrm{ml}$. Keempat erlenmeyer yang telah berisikan bahan diaduk hingga homogen lalu ditutup dengan alumunium foil, kemudian keempat erlenmeyer dimasukkan ke dalam autoklaf untuk disterilkan pada suhu $121^{\circ} \mathrm{C}$ selama 15 menit.

\section{Pengujian Aktivitas Antibakteri}

Pengujian antibakteri Fraksi nHeksana, Metanol, dan air dari ekstrak ascidian Lissoclinum sp. pada penelitian ini menggunakan konsentrasi dari tiap Fraksi yaitu 200 mg/ml (200.000 ppm) dan diambil $50 \mu \mathrm{l}$ menggunakan mikropipet untuk ditotolkan pada setiap kertas cakram. Metode yang digunakan pada penelitian ini adalah difusi agar (disc diffusion Kirby and Bauer Method). Pengujian aktivitas antibakteri untuk tiap bakteri dilakukan 3 kali ulangan sekaligus pada 3 cawan petri yang sama.

\section{Pengamatan dan Pengukuran}

Pengamatan dilakukan setelah 1x24 jam masa inkubasi. Hasil data pengukuran yang diperoleh berupa diameter zona bening dari setiap fraksi ekstrak sampel spons diukur menggunakan mistar dan dibandingkan dengan zona bening kontrol positif.

\section{HASIL DAN PEMBAHASAN}

\section{Pengambilan dan Identifikasi Sampel}

Sampel yang diperoleh yaitu ascidian Lissoclinum sp. (Gambar 2) dengan ciri-ciri seperti lembaran 


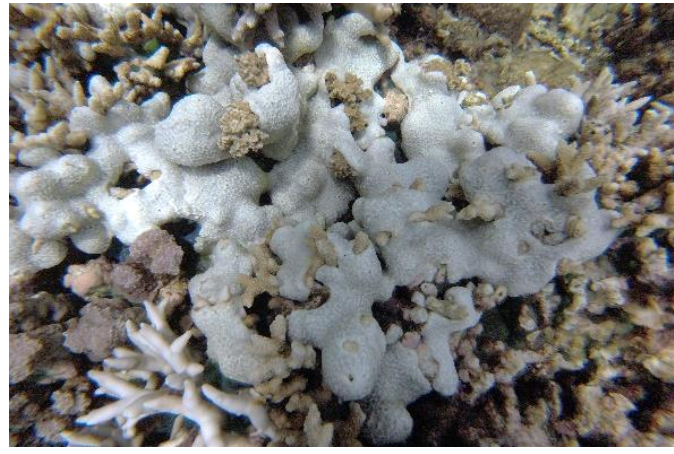

Gambar 2. Ascidian Lissoclinum sp.

bergelombang, menempel di karang, dan berwarna kelabu dengan corak hijau. Berat basah sampel yang diperoleh sebanyak $840 \mathrm{~g}$.

\section{Ekstraksi Ascidian Lissoclinum sp.}

Setelah dilakukan proses ekstraksi dengam metode maserasi bertahap sebanyak 3×24 jam. Filtrat yang diperoleh dari keseluruhan proses maserasi, dievaporasi dan didapatkan ekstrak kasar sebanyak 40,5 g.

\section{Partisi}

Dari ekstrak ascidian yang dipartisi sebanyak $15 \mathrm{~g}$, didapatkan fraksi air sebanyak $1.030 \mathrm{mg}$, fraksi metanol sebanyak $120 \mathrm{mg}$ dan fraksi n-heksana sebanyak $1.088 \mathrm{mg}$. Fraksi air dan fraksi nheksana memiliki berat yang hampir sama dan relatif banyak dibandingkan dengan fraksi metanol. Bisa dijelaskan bahwa senyawa yang bersifat semipolar dari ascidian Lissoclinum sp. lebih sedikit dibandingkan dengan senyawa yang bersifat polar dan non polar.

\section{Pengujian Aktivitas Antibakteri}

Aktivitas antibakteri dilihat dengan adanya zona hambat yang tampak pada sekitar kertas cakram. Pengamatan dan pengukuran zona hambat menggunakan mistar dilakukan pada media bakteri bakteri $S$. saprophyticus, $B$. megaterium, $P$. aeruginosa, E. coli. Hasilnya pada media bakteri S. saprophyticus (Gambar 3) pada ketiga ulangan hanya fraksi air, fraksi metanol, ekstrak etanol dan kontrol positif yang menunjukkan zona hambat (inhibitory zone). Fraksi air menunjukkan diameter zona hambat pada ulangan I $(8,00 \mathrm{~mm})$, ulangan II $(8,00 \mathrm{~mm})$, dan ulangan III $(8,00$ $\mathrm{mm}$ ). Fraksi metanol menunjukkan diameter zona hambat pada ulangan I $(7,50 \mathrm{~mm})$, ulangan II $(7,50 \mathrm{~mm})$ dan ulangan III (7,50 mm). Kemudian ekstrak etanol menunjukkan diameter zona hambat pada ulangan I $(7,00 \mathrm{~mm})$, ulangan II $(7,00$ $\mathrm{mm})$ dan ulangan III (7,00 $\mathrm{mm})$. Selanjutnya kontrol positif menunjukkan diameter zona hambat pada ulangan I $(29,50 \mathrm{~mm})$, ulangan II $(29,00 \mathrm{~mm})$ dan ulangan III (28,00 $\mathrm{mm})$.

Pada media bakteri $B$. megaterium (Gambar 4) pada ketiga ulangan hanya fraksi air dan kontrol positif yang menunjukkan zona hambat (inhibitory zone). Fraksi air menunjukkan diameter zona hambat pada ulangan I $(8,00 \mathrm{~mm})$, ulangan II $(8,00 \mathrm{~mm})$, dan ulangan III $(8,00$ $\mathrm{mm}$ ). Selanjutnya kontrol positif menunjukkan diameter zona hambat pada ulangan I $(24,00 \mathrm{~mm})$, ulangan II $(25,00$ $\mathrm{mm})$ dan ulangan III (24,50 $\mathrm{mm})$.

Pada media bakteri $P$. aeruginosa (Gambar 5) pada ketiga ulangan hanya fraksi air, ekstrak etanol, dan kontrol positif yang menunjukkan zona hambat (inhibitory zone). Fraksi air menunjukkan diameter zona hambat pada ulangan I $(7,00 \mathrm{~mm})$, ulangan II $(7,00 \mathrm{~mm})$, dan ulangan III 7,00 $\mathrm{mm})$. Kemudian ekstrak etanol menunjukkan diameter zona hambat pada ulangan I $(6,50 \mathrm{~mm})$, ulangan II $(6,50 \mathrm{~mm})$ dan ulangan III $(6,50 \mathrm{~mm})$. Selanjutnya kontrol positif menunjukkan diameter zona hambat pada ulangan I $(26,00 \mathrm{~mm})$, ulangan II $(26,00 \mathrm{~mm})$ dan ulangan III (26,50 mm).

Pada media bakteri E. coli (Gambar 6) pada ketiga ulangan hanya fraksi air, ekstrak etanol, dan kontrol positif yang menunjukkan zona hambat (inhibitory zone). Fraksi air menunjukkan diameter zona hambat pada ulangan I $(8,00 \mathrm{~mm})$, ulangan II (8,00 mm), dan ulangan III 8,00 $\mathrm{mm})$. Kemudian ekstrak etanol menunjukkan diameter zona hambat pada ulangan I $(7,00 \mathrm{~mm})$, ulangan II $(6,50 \mathrm{~mm})$ dan ulangan III $(7,00 \mathrm{~mm})$. Selanjutnya kontrol positif menunjukkan diameter zona hambat pada ulangan I $(19,00 \mathrm{~mm})$, ulangan II $(19,50 \mathrm{~mm})$ dan ulangan III $(19,50 \mathrm{~mm})$. Kemudian keseluruhan data dirata-ratakan dan hasilnya dapat dilihat pada Tabel 1 dan Gambar 7. 

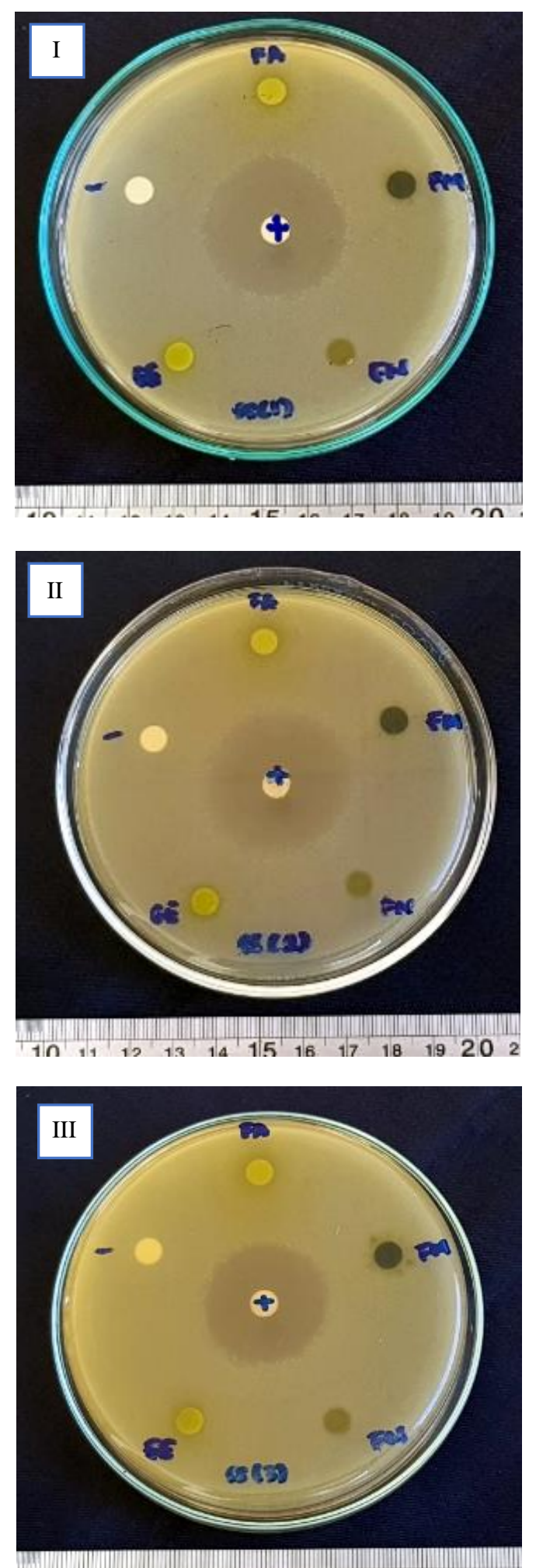

$\begin{array}{llllllllllll}10 & 11 & 12 & 13 & 14 & 15 & 16 & 17 & 18 & 19 & 20 & 2\end{array}$

Gambar 3. Hasil pengujian antibakteri pada media bakteri $S$. saprophyticus

Keterangan:

(FA) - Fraksi air

(EE) - Fraksi air

(FM) - Fraksi metanol (+) - Kloramfenikol

(FN) - Fraksi n-heksana (-) - Etanol
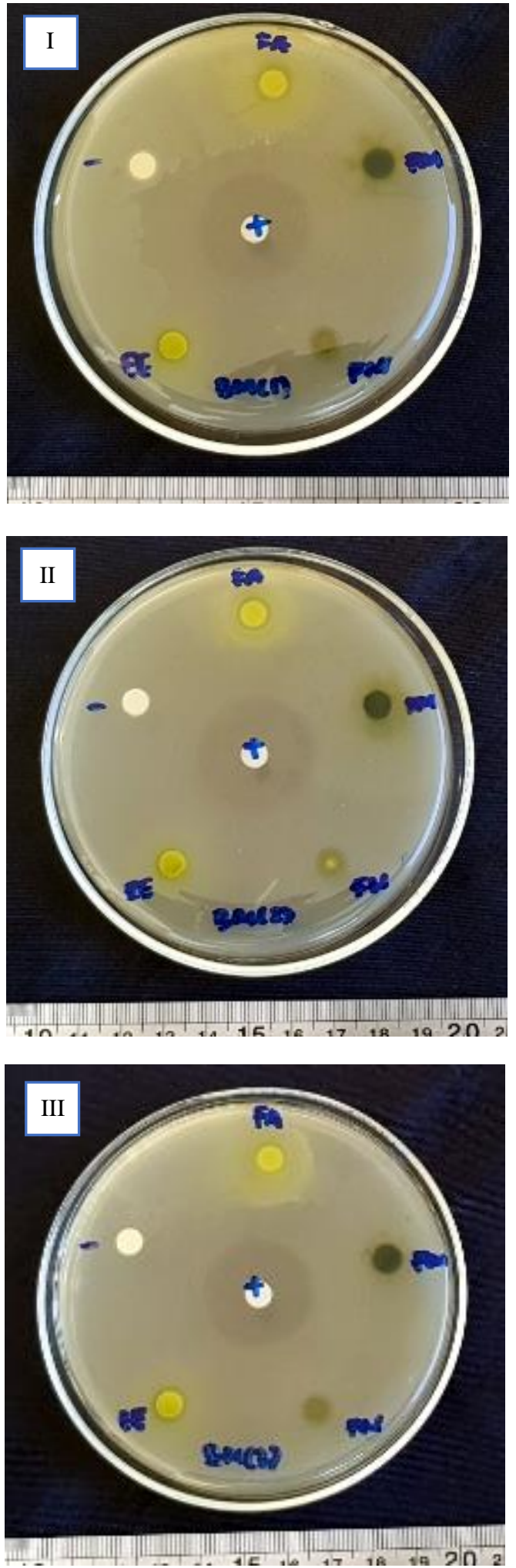

Gambar 4. Hasil pengujian antibakteri pada media bakteri $B$. megaterium.

Keterangan:

(FA) - Fraksi air (EE) - Fraksi air

(FM) - Fraksi metanol (+) - Kloramfenikol 
(FN) - Fraksi n-heksana (-) - Etanol


Gambar 5. Hasil pengujian antibakteri pada media bakteri $P$. aeruginosa

Keterangan:

(FA) - Fraksi air

(EE) - Fraksi air

(FM) - Fraksi metanol

(+) - Kloramfenikol

(FN) - Fraksi n-heksana

$(-)$ - Etanol

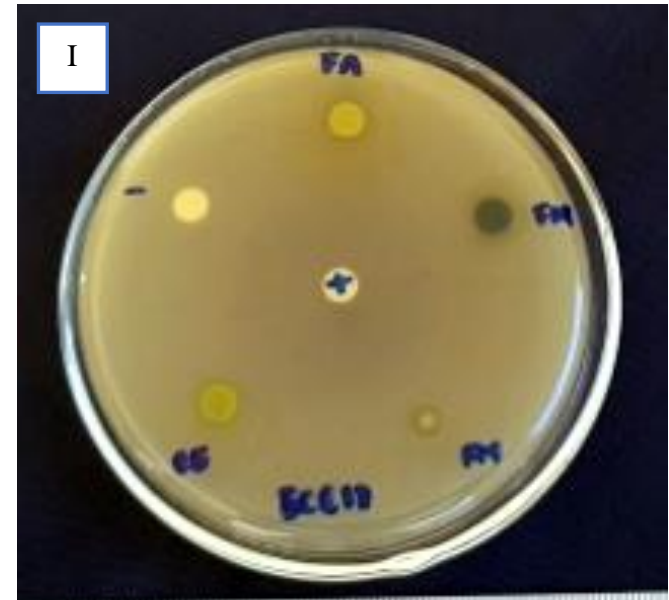

in if 12 is is 15 if is is is 20
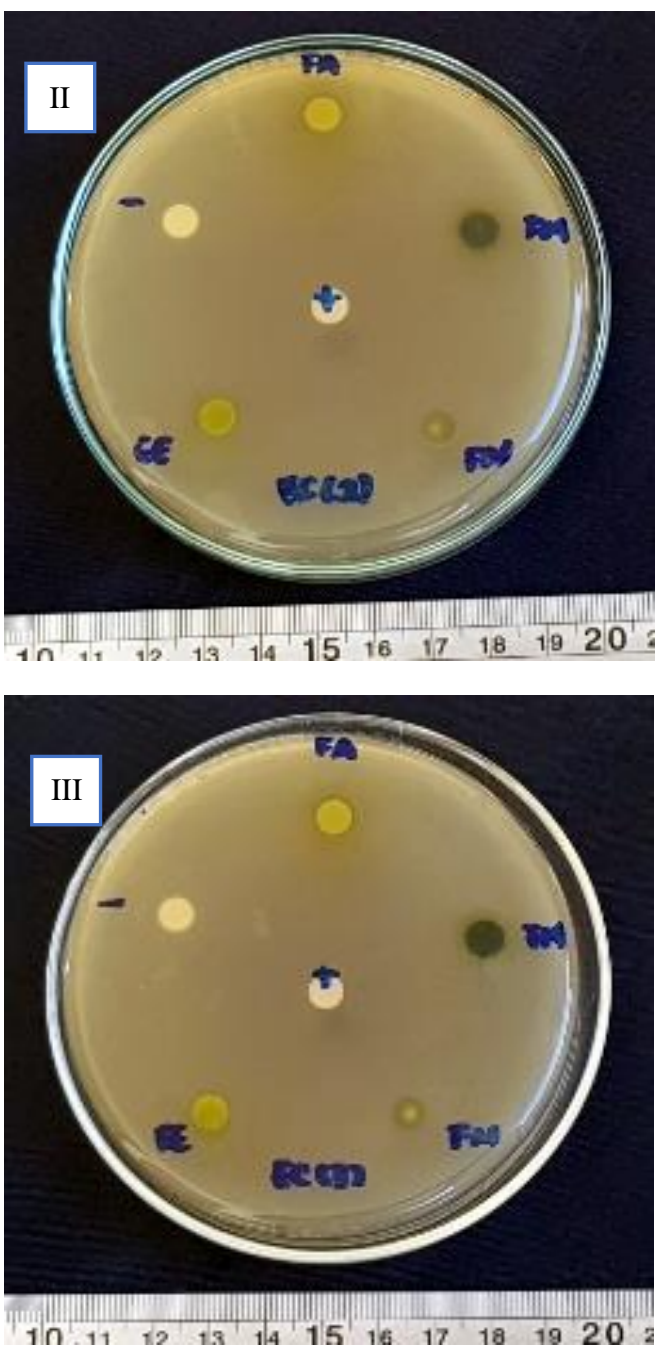

Gambar 6. Hasil pengujian antibakteri pada media bakteri $E$. coli

Keterangan:

(FA) - Fraksi air (EE) - Fraksi air

(FM) - Fraksi metanol (+) - Kloramfenikol

(FN) - Fraksi n-heksana (-) - Etanol 
Tabel 1. Rerata zona hambat ketiga fraksi, ekstrak etanol dan kontrol terhadap pertumbuhan bakteri S. saprophyticus, B. megaterium, P. aeruginosa, E. Coli..

\begin{tabular}{lcccc}
\hline \multirow{2}{*}{ Bahan Uji } & \multicolumn{4}{c}{ Rerata Zona Hambat Pada Media (mm) } \\
\cline { 2 - 5 } & S. saprophyticus & B. megaterium & P. aeruginosa & E. coli \\
\hline Fraksi Air & $8,00 \pm 0,00$ & $8,00 \pm 0,00$ & $7,00 \pm 0,00$ & $8,00 \pm 0,00$ \\
\hline Fraksi Metanol & $7,50 \pm 0,00$ & - & - & - \\
\hline Fraksi n-Heksana & - & - & - & - \\
\hline Ekstrak Etanol & $7,00 \pm 0,00$ & - & $6,50 \pm 0,00$ & $6,30 \pm 0,29$ \\
\hline Kontrol (+) & $28,80 \pm 0,00$ & $24,50 \pm 0,50$ & $26,20 \pm 0,29$ & $19,30 \pm 0,29$ \\
\hline Kontrol (-) & - & - & - & - \\
\hline
\end{tabular}

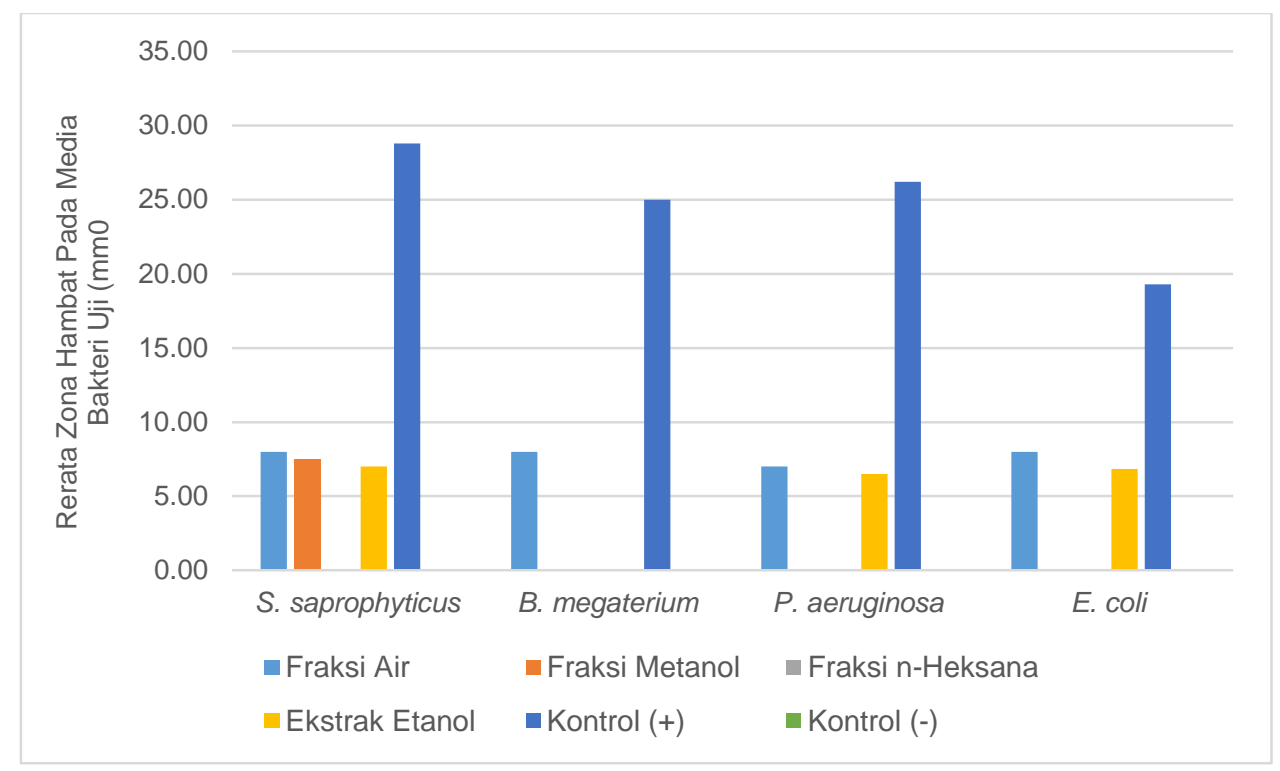

Gambar 7. Grafik rerata zona hambat ketiga fraksi, ekstrak etanol dan kontrol terhadap pertumbuhan bakteri $S$. saprophyticus, B. megaterium, $P$. aeruginosa, E. coli.

\begin{abstract}
Menurut Davis and Stout (1971) dalam Wewengkang et al. (2014) penggolongan kriteria kekuatan suatu bahan antibakteri, yakni diameter zona hambat $5 \mathrm{~mm}$ atau kurang dikategorikan lemah, dan zona hambat 5-10 mm dikategorikan sedang, sedangkan diameter zona hambat 10-20 $\mathrm{mm}$ dikategorikan kuat dan bahkan yang melebihi dari $20 \mathrm{~mm}$ dikategorikan sangat kuat. Dari Tabel 1 dapat dijelaskan bahwa fraksi air memberikan daya hambat terhadap pertumbuhan keempat bakteri uji yaitu bakteri $S$. saprophyticus, $B$. megaterium, $P$. aeruginosa, $E$. coli. Hal ini ditunjukkan dengan adanya zona hambat $8,00 \pm 0,00 \mathrm{~mm}$ (tergolong sedang) pada bakteri $S$. saprophyticus, $8,00 \pm 0,00 \mathrm{~mm}$ (tergolong sedang) pada bakteri $B$.
\end{abstract}

megaterium, 7,00 $\pm 0,00 \mathrm{~mm}$ (tergolong sedang) pada bakteri $P$. aeruginosa, dan $8,00 \pm 0,00 \mathrm{~mm}$ (tergolong sedang) pada bakteri $E$. coli. Selanjutnya fraksi metanol hanya memberikan daya hambat terhadap pertumbuhan bakteri $S$. saprophyticus dengan zona hambat yang ditunjukkan $7,50 \pm 0,00 \mathrm{~mm}$ (tergolong sedang). Pada fraksi n-heksana tidak memberikan daya hambat terhadap pertumbuhan keempat bakteri uji yaitu bakteri $S$. saprophyticus, $B$. megaterium, $P$. aeruginosa, $E$. coli. Hal ini dikarenakan fraksi n-heksana tidak menunjukkan zona hambat pada keempat media bakteri uji dari data yang diperoleh. Pada ekstrak etanol menunjukkan adanya daya hambat pada ketiga bakteri uji yaitu $S$. saprophyticus, $P$. aeruginosa, E. coli. Daya hambat yang ditunjukkan lebih lemah 
dibandingkan dengan yang ditunjukkan fraksi air, yaitu 7,00 $\pm 0,00 \mathrm{~mm}$ (tergolong sedang) pada bakteri $S$. saprophyticus, $6,50 \pm 0,00 \mathrm{~mm}$ (tergolong sedang) pada bakteri $P$. aeruginosa, dan $6,30 \pm 0,29 \mathrm{~mm}$ (tergolong sedang) pada bakteri $E$. coli. Menurut Pelczar dan Chan (1986) dalam Kumayas et al. (2015) seperti terlihat pada Tabel 4, uji aktivitas antibakteri fraksi metanol cenderung tidak dapat menghambat pertumbuhan pada bakteri Gram negatif $P$. aeruginosa dan $E$. coli, tetapi dapat menghambat pertumbuhan bakteri Gram positif $S$. saprophyticus, respon yang berbeda dari kedua golongan bakteri terhadap senyawa ini dikarenakan adanya perbedaan kepekaan Gram positif dan bakteri Gram negatif terhadap senyawa antibakteri yang terkandung dalam fraksi metanol. Bakteri Gram positif cenderung lebih sensitif terhadap komponen antibakteri daripada bakteri Gram negatif.

Dari hasil yang ditunjukkan di atas daya hambat bakteri dikarenakan struktur dari dinding sel bakteri Gram positif lebih sederhana hingga lebih mudahlah senyawa antibakteri untuk masuk ke dalam sel dan menemukan sasarannya, sedangkan struktur dinding sel dari bakteri Gram negatif lebih kompak dan padat dan terdiri atas 3 lapisan salah satunya yaitu peptidoglikan (Posangi dan Bara, 2014; Bara et al., 2015). Sehingga daya hambat bakteri yang terjadi lebih kuat pada bakteri golongan Gram positif.

Pada penelitian yang telah dilakukan tampak bahwa kontrol positif kloramfenikol jauh lebih efisien untuk menghambat pertumbuhan keempat bakteri uji yaitu $S$. saprophyticus $(28,80 \pm$ $0,00 \mathrm{~mm}), B$. megaterium $(24,50 \pm 0,50), P$. aeruginosa $(26,20 \pm 0,29)$, dan $E$. coli $(19,30 \pm 0,29)$. Faktor yang mempengaruhi hal di atas karena Minimum Inhibitory Concentration (MIC) kloramfenikol telah diketahui konsentrasi paling tepat untuk menghambat aktivitas pertumbuhan bakteri serta telah diketahui bahwa kloramfenikol merupakan antibiotik berspektrum luas, sedangkan untuk kemampuan senyawa antibakteri dari ascidian belum diketahui (Patel et al., 2014).
Kontrol negatif yang dalam penelitian ini etanol 95\% menunjukkan perbedaan terhadap kontrol positif maupun Fraksi sampel uji. Pada penelitian ini kontrol negatif berfungsi untuk melihat media yang digunakan tercemar atau tidak. Kontrol tersebut menunjukkan tidak adanya zona hambat pada pengujian antibakteri terhadap bakteri Gram positif $S$. saprophyticus dan B. megaterium juga terhadap bakteri Gram negatif $P$. aeruginosa dan $E$. coli. Hal ini mengindikasikan bahwa kontrol negatif yang digunakan tidak berpengaruh pada uji bioaktivitas antibakteri sampel, sehingga daya hambat yang terbentuk tidak dipengaruhi oleh pelarut melainkan karena aktivitas senyawa aktif yang terdapat pada ascidian Lissoclinum sp. baik pada fraksi maupun ekstrak etanol.

Selanjutnya dari hasil pengujian antibakteri didapatkan bahwa senyawa antibakteri dari ascidian Lissoclinum sp. bersifat polar dikarenakan hasil yang ditunjukkan yaitu hanya fraksi polar yakni fraksi air yang konstan dapat menghambat pertumbuhan keempat bakteri uji. Dibandingkan dengan hasil penelitian Kumayas et al. (2015), dari ascidian Polycarpa aurata didapatkan senyawa antibakteri bersifat semipolar dikarenakan hasil yang diperoleh hanya fraksi semipolar yakni fraksi kloroform yang konstan menghambat pertumbuhan bakteri $S$. aureus dan E. coli.

Senyawa antibakteri dapat digolongkan juga sebagai spektrum luas dan spektrum sempit. Spektrum luas artinya senyawa tersebut bekerja aktif terhadap banyak jenis bakteri baik bakteri Gram positif dan bakteri Gram negatif. Sedangkan spektrum sempit artinya suatu senyawa bekerja aktif hanya terhadap satu golongan bakteri saja baik hanya pada bakteri Gram positif ataupun hanya pada bakteri Gram negatif (WHO, 2014). Hasil penelitian ini menunjukkan bahwa senyawa antibakteri dari ascidian Lissoclinum sp. yang terdapat pada fraksi air tergolong berspektrum luas dikarenakan kemampuannya menghambat bakteri Gram positif dan Gram negatif. Hal ini diduga bahwa di alam ascidian memproduksi senyawa antibakteri dalam 
bentuk metabolit sekunder untuk melawan semua ancaman yang dihadapinya.

Hasil pengujian antibakteri juga menunjukkan bahwa senyawa antibakteri dari ascidian Lissoclinum sp. tergolong sedang. Hal ini bisa dihubungkan dengan produksi senyawa metabolit sekundernya juga saat di alam. Energi yang banyak diperlukan untuk memproduksi senyawa dalam jumlah banyak (Rinehart, 1992). Oleh karena itu, bisa saja ascidian Lissoclinum sp. hanya memproduksi senyawa antibakterinya dalam jumlah sedikit. Selain itu, tekanan lingkungannya juga berpengaruh dalam hal produksi metabolit sekunder antibakteri dari ascidian Lissoclinum sp., apabila tekanan lingkungannya relatif rendah maka senyawa yang akan dihasilkan juga pasti sedikit. Kemudian apabila tekanan lingkungannya relatif tinggi maka senyawa yang dihasilkan akan banyak (Rinehart, 1992). Bisa dikatakan dari hasil penelitian ini ascidian Lissoclinum sp. yang dijadikan sampel hidup pada areal dengan tekanan lingkungan yang rendah sehingga memproduksi senyawa metabolit sekunder dengan aktivitas antibakteri yang sedang.

\section{KESIMPULAN}

Berdasarkan penelitiam yang dilakukan dapat disimpulkan bahwa Pertama ekstrak ascidian Lissoclinum sp. berhasil diperoleh sebanyak 40,5 gram melalui proses maserasi $3 x$ dengan pelarut etanol 95\% dan evaporasi. Kedua, pemisahan ekstrak etanol ascidian Lissoclinum sp. menjadi beberapa fraksi dengan teknik partisi menghasilkan 3 fraksi, yaitu fraksi air sebanyak $1.030 \mathrm{mg}$, fraksi metanol sebanyak $120 \mathrm{mg}$, dan fraksi n-heksana sebanyak 1.088 mg. Ketiga, pengujian antibakteri menunjukkan senyawa antibakteri ascidian Lisscolinum sp. bersifat polar karena terdapat pada fraksi air dan aktivitas antibakteri ditunjukkan terhadap keempat bakteri uji yang artinya senyawa tersebut berspektrum luas.

\section{DAFTAR PUSTAKA}

$\begin{array}{ccc}\text { Ali, H.A.J., Tamilselvi, M. 2016. Ascidians } \\ \text { in Coastal } & \text { Water: } & A \\ \text { Comprehensive Inventory of } & \end{array}$

Ascidian Fauna from the Indian Cost. Springer International Publishing. Switzerland.

Bara, R.A., Kandou, G.D., Ola, A.R.B., Posangi, J. 2015. Analisis Senyawa Antibiotik dari Jamur Simbion yang Terdapat Dalam Ascidians Didemnum molle di Sekitar Perairan Bunaken Sulawesi Utara. Jurnal LPPM Bidang Sains dan Teknologi. 2(2):7-8.

Chan, S.T.S., Pearce, A.N., Januario, A.H., Page, M.J., Kaiser, M., McLaughlin, R.J., Harper, J.L., Webb, V.L., Barker, D., Copp, B.R. 2011. Antiinflammatory and Antimalarial Meroterpenoids from the New Zealand. J. Org. Chem. 76(21): 9151-6

Colin, P.L., Arneson, A.C. 1995. Tropical Pasific Invertebrates: A Field Guide to the Marine Invertebrates Occuring on Tropical Pasicif Coral Reefs, Seagrass Beds and Mangroves. Coral Reef Press. Beverly Hills, California. USA.

Dahuri, R. 2003. Keanekaragaman Hayati Laut: Aset Pembangunan Berkelanjutan Indonesia. Gramedia Pustaka Utama. Jakarta.

Donia, M.S., Wang, B., Dunbar, D.C., Densai, P.V., Patny, A., Avery, M., Hamann, M.T. 2008. Mollamides B and $\mathrm{C}$, Cyclic Hexapeptides from the Indonesian Tunicate Didemnum molle. J. Nat. Prod. 71(6): 941-945.

Kawung, N.J., Mangindaan, R.E.P., Rompas, R.M., Chasanah, E., Kapoyos, M., Abdjul, B., Januar, H.I., Fajarningsih, D., Sumagando, A. 2017. Cytotoxic Anticancer from New Compound Unsrat-sinularine of Soft Coral Sinularia sp. from Bunaken Island, Manado, Indonesia. Int. J. Drug. Dev \& Res. 9(3):1-4.

Kiran, N., Siddiqui, G., Khan, A.N., Ibrar, K., Tushar, P. 2014. Extraction and Screening of Bioactive Compounds with Antimicrobial Properties from Selected Species of Mollusk and 
Crustacean. J. Clin. Cell. Immunol. 5(1): 1-5.

Kumayas, A.R., Wewengkang, D.S., Sudewi, S. 2015. Aktifitas Antibakteri dan Karakteristik Gugus Fungsi Dari Tunikata Polycarpa aurata. Pharmacon. 4(1):32-44.

Li, J.L., Xiao, B., Park, M., Yoo, E.S., Shin, S., Hong, J., Chung, H.Y., Kim, H.S., Jung, J.H. 2012. PPAR-Y agonistic metabolites from the ascidian Herdmania momus. J. Nat. Prod. 75(12): 2082-2087.

Luissandy, Sumilat, D.A., Lintang, R.A.J. 2017. Bioaktivitas Anitbakteri Fraksi ODS Spons Agelas sp. dari Perairan Pulau Bunaken. Jurnal Pesisir dan Laut Tropis. 2(1):22-31.

Mangindaan, R.E.P., dan Taroreh., R.Y. 2013. Pengujian Aktivitas Larvasida dari Ekstrak Ascidian Lissoclinum pattela Terhadap Larva Nyamuk Aedes aegypti. Jurnal Pesisir dan Laut Tropis. 3(1): 13-17.

Moerid. M.S., Mangindaan, R.E.P., Losung, F. 2013. Uji Aktivitas Larvasida Nyamuk Aedes aegypti dari Beberapa Ekstrak Ascidian. Jurnal Pesisir dan Laut Tropis. 1(1): 15-20.

Nakamura, Y., Kato, H., Nishikawa, T., Iwasaki, N., Suwa, Y., Rotinsulu, H., Losung, F., Maarisit, W., Mangindaan, R.E.P., Morioka, H., Yokosawa, H., Tsukamoto, S. 2013. Siladenoserinols A-L: New Sulfonated Serinol Derivates from a Tunicates as Inhibitors of p53Hdm2 Interaction. Org. Let. 15(2): 322-325.

Ngantung, A.E.C., Bara, R.A., Sumilat, D.A. 2016. Uji Aktivitas Antibakteri dari Spons Dictyonella funicularis dan Phyllospongia lamellosa yang diambil pada Perairan Bunaken. Jurnal Pesisir dan Laut Tropis. 2(1): 10-16.

Nowin, E., Warouw, V., Rimper, J.R.T.S.L., Paulus, J.J.H., Pangkey, H., Sumilat, D.A. 2018. Penapisan
(Skirining) Aktivitas Antibakteri Beberapa Ekstrak Spons dari Teluk Manado. Jurnal Pesisir dan Laut Tropis. 1(1):21-32.

Ompi, M. 2016. Larva Avertebrata Dasar Laut: Ekologi dan Tingkah Laku Larva. Deepublish. Yogyakarta. 137 hal.

Pasodung, A.P., Losung, F., Angkouw, E.D., Lintang, R., Mantiri, D.M.H., Sumilat, D.A. 2018. Jurnal Pesisir dan Laut Tropis, 1(1):44-51.

Posangi, J. dan Bara, R.A. 2014. Analisis Aktivitas Dari Jamur Endofit Yang Terdapat Dalam Tumbuhan Bakau Avicennia marina di Tasik Ria Minahasa. Jurnal Pesisir dan Laut Tropis. 1(1):6-7.

$\begin{array}{crr}\text { Rinehart, K.L. } & \text { 1992. } & \text { Secondary } \\ \text { metabolites } & \text { from } & \text { marine } \\ \text { organisms. } & \text { Ciba. } & \text { Found. } \\ \text { Symp.171:236-49. } & \end{array}$

Rumengan, A.P. 2010. Uji Larvasida Nyamuk (Aedes aegypti) dari Ascidian (Didemnum molle). Jurnal Perikanan dan Kelautan. 6(2):8386.

Shenkar, N. dan Loya, Y. 2008. Ecology and systematics of the ascidian fauna in the Gulf of Eilat (Aqaba). In: F.D. Por (Eds.), Aqaba-Eilat, the Improbable Gulf. Environment, Biodiversity and Preservation ( $p$. 235-237). Jerusalem: Magnes Press.

Sima, P. dan Vetvicka, V. 2011. Bioactive substances with anti-neoplastic efficacy from marine invertebrates: Bryozoa, Mollusca, Echinodermata and Urochordata. World. J. Clin. Oncol. 2(11):362-366.

Sumilat, D.A., Wewengkang, D.S., Paruntu, C.P., Rumampuk, N.D.C., Rotinsulu, H. 2014. Cytotoxic Activity of Ascidian Eudistoma sp. From Mantehage Island Manado. Jurnal LPPM Bidang Sains dan Teknologi. 1(1):86-89.

Sumilat, D.A., Wewengkang, D.S., Paruntu, C.P., Rotinsulu, H. 2017. 
Inhibitory Activities of Ascidian Herdmania momus on the Colony Formation of Chinese Hamster V79 Cells, collected in Manado North Sulawesi, Indonesia. Jurnal of Asean Studies and Maritime Issues. 3 (5):13-19.

Sumilat, D.A., Wewengkang, D.S., Rotinsulu, H., Yamazaki, H., Oda, T., Ukai, K., Namikoshi, M. Bioactivity of extracts from ascidians collected in North Sulawesi as seeds of marinederived drugs. AACL Bioflux. 11(2): 516-524.

Tatsuta, T., Hosono, M., Rotinsulu, H., Wewengkang, D.S., Sumilat, D.A., Namikoshi, M., Yamazaki, H. 2017. Lissoclibadin 1, a Polysulfur Aromatic Alkaloid from the Indonesian Ascidian Lissoclinum cf. badium, Induces CaspaseDependent Apoptosis in Human Colon Cancer Cells and Suppresses Tumor Growth in Nude Mice. J. Nat. Prod. 80 (2):499-502.

Urda, C., Fernández, R., Rodríguez, J., Pérez, M., Jiménez, C., Cuevas, C. 2017. Bistratamides $\mathrm{M}$ and $\mathrm{N}$, Oxazole-Thiazole Containing Cyclic Hexapeptides Isolated from Lissoclinum bistratum Interaction of Zinc (II) with Bistratamide K. Mar. Drugs. 15(7):209.

Wagey, B.T. 2017. Morphometric analysis of congeneric seagrasses (Cymodocea rotundata and Cymodocea serrulata) in the coastal areas of Bunaken National Park, North Sulawesi, Indonesia. AACL Bioflux, 10(6):1638-1646.

Wang, W., Nam, S.J., Lee, B.C., Kang, H. 2008. Beta-carboline alkaloids from a Korean tunicate Eudistoma sp.. J. Nat. Prod. 71(2):163-6.

Wewengkang, D.S., Sumilat, D.A., Rotinsulu, H. 2014. Sitotoksitas Ekstrak Kasar Ascidian dari Pulau Bunaken. Jurnal LPPM Bidang Sains dan Teknologi. 1(1):86-89.
WHO. 2014. Antmicrobial resistance: global report on survaillance 2014. World Health Organization. p 257. 